\title{
Álbuns de retratos, infÂNCIAS ENTRECRUZADAS E CULTURA LÚDICA: MEMÓRIA E FOTOGRAFIA NA BRINQUEdoteCA HAPI
}

Cristina Laclette Porto

Esta tese apresenta parte da história da Brinquedoteca Hapi, um espaço dedicado às crianças, coordenado pela autora durante 16 anos e que tinha como eixo de ação brinquedos e brincadeiras. A reconstrução dessa trajetória partiu de diferentes suportes de memória, sendo que a fotografia revelou-se um material fundamental. A pesquisa exigiu o aprofundamento teórico em torno das concepções de história, memória, narrativa, brinquedo e cultura lúdica. Trata-se de um texto polifônico no qual é possível destacar como interlocutores privilegiados os seguintes autores: Walter Benjamin, Maurice Halbwachs, Mikail Bakhtin, Hannah Arendt, Roland Barthes, Gilles Brougère, Beatriz Sarlo, Jeanne Marie Gagnebin, Ecléa Bosi, Gilberto Velho, Boris Kossoy, Miriam Moreira Leite, entre outros. A brinquedoteca tinha como propósito ser uma porta aberta para os museus, mas seu projeto revelou-se mais amplo ao criar uma pedagogia da ludicidade associada a uma pedagogia da imagem, ambas voltadas para a preservação de um patrimônio não-tangível que é o brincar. A tese mostra a importância da troca entre as gerações para o reconhecimento de que as histórias, ao serem contadas, se comprometem com o futuro e defende a ideia de que o trabalho desenvolvido com as crianças e suas famílias, em brinquedotecas, pode se constituir em um caminho fértil na luta contra o empobrecimento da experiência (Verfall der Erfahrung) engendrado pela sociedade contemporânea e anunciado por Walter Benjamin.

\section{BANCA:}

Solange Jobim e Souza (Orientadora)

Ana Maria Mauad de Sousa Andrade Essus

Eclea Bosi

Margarida de Souza Neves

Sonia Kramer

Data da defesa: 13/04/2010 